\title{
A coordinated satellite and terrestrial microwave backhaul for cellular mobile in remote and regional Australia
}

\author{
Andrew Crouch \\ Centre for Appropriate Technology, Alice Springs \\ Stan Davies \\ Consultant to Broadband for the Bush Alliance
}

\begin{abstract}
For several years prior to the Australian Federal elections in September 2013, Commonwealth Government telecommunications policy and legislation focussed exclusively on the fixed services National Broadband Network. This distracted broader public attention from the need for cellular mobile expansion in the more sparsely populated areas of the country. Commercial returns in these areas are clearly inadequate for unilateral private operator investment, making government participation crucial. Thus a commitment from the newly elected Coalition Government for a Mobile Black Spot co-investment programme marks a significant change of prospects for remote and regional Australia.

This paper proposes that the joint program should commence with a comprehensive financial and technical study of backhaul and base station technology options, to identify the most cost effective approaches. These options include the coordinated provisioning of modern satellite and terrestrial backhaul systems, utilising and upgrading existing HCRC microwave system infrastructure, and the implementation of small cell base station types.

It is especially timely for these opportunities to be considered now, during the present pre-launch design and construction phase for the NBN Ka band satellites.
\end{abstract}

\section{Introduction}

Large distances and low population densities continue to make the delivery of telecommunications services to much of remote and regional Australia both challenging and costly ${ }^{\mathrm{i}}$. Thus in many cases government subsidies play an essential role in the provision and operation of services.

In regard to cellular mobile services, a policy commitment of $\$ 100 \mathrm{~m}$ for regional and remote cellular mobile black spot funding made shortly prior to the recent Federal elections by the then Coalition Opposition is significant (Coalition Mobile Blackspots. 2013), (Coalition NBN 2013). With the subsequent change of government it brings a change from prior Federal policy that left mobile coverage expansion to private network operators and state and territory governments, allowing regional and remote area coverage growth to slow 
significantly. Thus Australians without mobile service in many remote and regional locations, having waited for more than six years for such a Federal Government programme, now have a commitment for action, albeit one that will require more funding over the longer term.

The new policy aligns with a recommendation for regional and remote mobile service expansion made by the 2011/12 Regional Telecommunications Review (DBCDE. 2012). It likewise responds to numerous other calls for urgent action ${ }^{i i}$. Also it complements recent state and territory level initiatives, including the Regional Mobile Communications Project for remote communities and highways in WA, jointly funded by the Western Australian Government and Telstra (Delimiter. 2012) and the joint Northern Territory Government Telstra agreement to provide mobile coverage in eight remote communities (Giles A. 2013).

Whilst supporting all of these initiatives, we believe there are a number of implementation and technological and/or cost savings opportunities that ought to be considered in the rollout of the new funding programme. In this context, we propose that the program should commence with, or be preceded by, a comprehensive technical and financial assessment of all potential implementation options. This assessment should be undertaken with full government, industry and end-user group representation. It should consider:

- A coordinated approach to backhaul, employing modern satellite and terrestrial microwave systems, the physical infrastructure of the existing Telstra High Capacity Radio Concentrator (HCRC) network, and other backhaul systems including those for the NBN fixed wireless broadband services.

- The implementation of small-cell mobile base station types.

Satellite mobile services might arguably be included in this assessment as an alternative to expanding terrestrial cellular mobile coverage. However, the high tariffs associated with satellite mobile, particularly for calls terminating on the mobile device, limit their application largely to high value commercial and emergency operations.

It is beyond the scope of this paper to suggest any specific policies for allocating the available funding across the various regions of the country, or for increasing the funding by extending the Universal Service Obligation (USO) to embrace mobile services; e.g. see (ACCAN RTR. 2011), (Corner S. 2012). Our purpose is rather to highlight technical and provisioning opportunities to make the available dollars go further.

We make no reference to optical fibre backhaul, which is the preferred transmission medium for very high capacity long distance main routes passing through regional and remote areas and for numerous shorter high capacity spur routes ${ }^{\text {iii }}$. New optical fibre systems and questions of employing add-drop multiplexers or possible dark fibre in existing fibre routes 
will be addressed as a matter of course by any expert group tasked with undertaking the proposed assessment. Furthermore, the majority of localities most in need (of cellular mobile coverage) necessitate backhaul route distances appreciably greater than those for which optical fibre would be cost competitive ${ }^{\text {iv }}$.

Our recommendations are discussed in greater detail in the body of the paper below. Although the Australian telecommunications industry is well versed in the particular systems referred to, the authors have not encountered any public proposals by others calling for them to be considered in the way put forward here.

\section{Complementary Backhaul System and Base Station Possibilities}

\section{Satellite Backhaul}

We propose that satellite backhaul be considered in the study for the following reasons: -

- The technology's distance-independence and ease of remote installation can make it the best type for high priority or temporary services. It can also be the most viable option for difficult locations such as islands, or very long routes in remote areas.

- Satellite systems utilising modern flexible operational control features in conjunction with low cost VSAT ground terminals and micro-cell mobile base stations are uniquely suited for isolated locations with small populations.

- The scheduled introduction in 2015 of two very high capacity Ka-band multi-beam satellites for Australian NBN fixed services may offer a window of opportunity to meet new mobile backhaul requirements.

Communications satellites have been employed for mobile backhaul for some decades. However for much of that time various limiting factors, including high satellite launch costs and inherently inflexible traditional transmission and call-routing systems, have confined applications to overseas countries with large population centres and inadequate terrestrial trunking infrastructure. In recent years many technical advances have made this form of backhaul much more attractive to network operators. These advantages are listed in Appendix II and include flexible dynamic transponder capacity assignment, local call routing, very high capacity multi-beam Ka-band satellites and various power saving features. Furthermore, the parallel emergence of smaller "Micro-cell" cellular mobile base station types, discussed further below, has contributed markedly to the practicality of servicing small remote communities ${ }^{v}$ (Anderson T. \& Mavrakis D. 2009), (Bright, J. \& Mavrakis, D. 
2012), (Chambers D. 2012), (Informa 2012). Remote cellular mobile networks with satellite backhaul are now being extensively employed in many overseas countries including Africa, S.E. Asia and South America (Milano Teleport, 2011), (Holmes M. 2012), (Gilat 2013), (Intelsat 2010), (Cox J. 2011).

The technology has begun to be employed in Australia, albeit on a very limited basis. For example Optus provides mobile services via satellite backhaul both to Birdsville (Venkatramani V. 2010)and to the Kimberley Diamond Company remote site (Optus 2011). Also Telstra and Ericsson provide $3 \mathrm{G}$ mobile services via satellite backhaul, again to Birdsville (Telstra 2011), (Venkatramani V. 2010).

These Australian installations are of recent origin. Furthermore, although Birdsville is a small outback township, its annual race meeting has an iconic national reputation: at race time the population expands many times with an influx of thousands of visitors. With such an elevated national profile it is logical that network operators would endeavor to establish their presence there. Thus the existence of satellite backhaul at Birdsville is not a reliable indicator that network operators are likely to establish such facilities in other similarly small outback townships.

In regard to the Kimberley Diamond Company site, we understand that the provision of cellular mobile facilities there is not unusual. Such remote mining sites are frequently staffed by well remunerated work forces relying on good phone communications to their far distant homes, particularly during their on-site leisure hours. Hence sites of this type should offer network operators good returns on investment, an attraction not generally shared by small non-mining remote Australian townships, communities, roadhouses and homesteads.

Having promoted consideration of satellite backhaul links, we are conscious they introduce or exacerbate a number of transmission impairments such as latency, jitter and packet loss. The high levels of compression typically used on these links also contribute. Although industry specialists have been addressing these issues for many years, the advent of broadband services has required new innovations for maintaining quality of service (QoS) e.g. see (LingSun Tan et. al. 2011), (iDirect. 2009) \& ( $\underline{3} 3 \mathrm{~b} \&$ Sofrecom). The new Australian NBN Satellites are doubtless being designed with advanced measures to guarantee satisfactory QoS for their intended fixed broadband applications. However if our recommendation for them to also be considered for cellular mobile backhaul is adopted, additional mitigation features may be required. Thus addressing these factors would form an important and timely part of the proposed study. 


\section{Terrestrial Microwave Radio Backhaul}

Terrestrial microwave radio systems will often offer the most economical means of providing the medium capacity backhaul function required for many remote and regional locations. These systems are being employed extensively both overseas and in Australia ${ }^{\text {vi }}$ and various advances have yielded increased benefits for network operators (Knoll Y. 2009), (Croy P. 2011), (Aravantinos E. 2011). A number of the advances listed for satellite systems in Appendix II also apply to modern terrestrial systems. In addition, the ability to integrate modern power-efficient transceivers with their antennas makes it possible for all transmission equipment to be mast-mounted. This eliminates or at least reduces the cost of security fenced ground enclosures and it also appreciably lowers transceiver-to-antenna signal loss, reducing transceiver transmit power and with it attendant site powering requirements.

\section{Potential for Upgrading HCRC Terrestrial Network for Mobile Backhaul}

Many localities in remote Australia receive telephony and low-speed data services via the High Capacity Radio Concentrator (HCRC) network, which came into being when its predecessor, the Digital Radio Concentrator System (DRCS) was upgraded with improved transceivers and associated equipment. Although this terrestrial microwave network has been replaced in some locations by other transmission facilities, much of it continues to fulfil the Universal Service Obligation (USO) for Standard Telephone Services (STS) and Public Payphone services.

With so many transceiver sites distributed throughout remote areas, powering and equipment problems have from time to time affected the operation of this network; e.g. see (Featherstone D. 2011), (Hutchinson J. 2012). However it is understood that the physical infrastructure (towers etc.), is well maintained. In fact the Hutchinson article describes Telstra's 2009 plans to “..... replace the decade-old HCRC networks with phone services based on a connection to the Next $G$ mobile network or with copper services underpinned by microwave backhaul" (ibid.). This project reportedly covered 200 HCRC networks servicing a total of 9000 remote residents, which indicates its large proposed scale. Although these modernisation plans were eventually halted, their existence suggests the feasibility of upgrading the existing HCRC physical infrastructure with modern microwave backhaul equipment. The prospect therefore exists for reducing the cost of introducing cellular mobile through the shared use of existing HCRC tower/physical infrastructure. 


\section{Flexible Mobile Base Station Sizes - Use of Small Cells}

Traditional "macro-cell" mobile base stations, now installed throughout the more populated areas of practically all countries, provide large cell coverage and commensurate service capacities. However, their relatively high cost and power consumption usually makes them unattractive for serving small isolated populations.

In comparison, the smaller micro-cell, pico-cell and femto-cell base station types, which were originally developed for boosting network capacities and alleviating shadowed black spot coverage problems within existing macro-cell footprints (Radio-Electronics.com) have been proposed for small isolated user populations. It is the reduced cost (including the cost of powering them) that is making the smaller cell types well suited to these latter applications (Talbot D. 2010), (RADWIN Ltd 2009), (Aravantinos E. 2011), (Anderson T. \& Mavrakis D. 2009), (Bright, J. \& Mavrakis, D. 2012).

\section{Complementarity of Satellite and Terrestrial Microwave Backhaul}

The complementary nature of satellite and terrestrial microwave backhaul systems derives from their different characteristics and associated costs. In this section we discuss this complementarity conceptually, assuming that the various expenditure items are as outlined in Appendix III.

Satellite backhaul systems require low incremental (i.e. per end-customer) capital expenditure, especially for Very Small Aperture Terminal (VSAT) ground stations. Their operating costs are nevertheless high because leasing satellite transponder capacity is

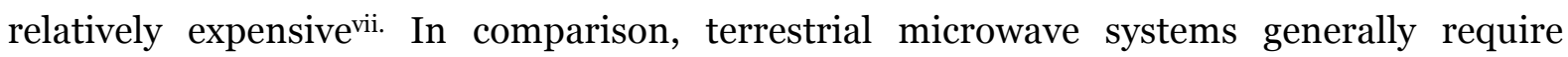
significantly higher capital outlays, especially when the backhaul distances and/or terrain requires several line-of-sight paths or hops. However terrestrial system operating costs almost invariably fall well below those for satellite systems of comparable capacity. The features of the respective systems are qualitatively summarised in Table $\mathbf{1}^{\text {viii. }}$ 
Table 1. Summary of satellite and terrestrial microwave system relative costs

\begin{tabular}{|c|c|c|c|}
\hline System & CapEx/remote location & OpEx/remote location & Flexibility \\
\hline $\begin{array}{c}\text { Leased satellite } \\
\text { transmission capacity }\end{array}$ & $\begin{array}{c}\text { Low (distance } \\
\text { independent) }\end{array}$ & High & Re-locatable at low cost \\
\hline $\begin{array}{c}\text { New Terrestrial } \\
\text { Microwave }\end{array}$ & $\begin{array}{c}\text { Medium for short } \\
\text { distances Increases to } \\
\text { High with increasing } \\
\text { number of system hops }\end{array}$ & $\begin{array}{c}\text { Low for short distances } \\
\text { Increases to Medium } \\
\text { with increasing number } \\
\text { of system hops }\end{array}$ & $\begin{array}{c}\text { Medium-to-High cost to } \\
\text { upgrade or re-locate } \\
\text { (depends on number of } \\
\text { system hops) }\end{array}$ \\
\hline $\begin{array}{c}\text { Upgrade to existing } \\
\text { Terrestrial Microwave } \\
\text { system }\end{array}$ & $\begin{array}{c}\text { Low for short distances } \\
\text { Increases to Medium } \\
\text { with increasing number } \\
\text { of system hops }\end{array}$ & $\begin{array}{c}\text { Low for short distances } \\
\text { Increases to Medium } \\
\text { with increasing number } \\
\text { of system hops }\end{array}$ & $\begin{array}{c}\text { Medium-to-High cost to } \\
\text { re-locate (depends on } \\
\text { number of system hops) }\end{array}$ \\
\hline
\end{tabular}

The capital and operating expenditure relativities set out in the first two rows of Table 1 demonstrate an important complementarity between the two system types. The satellite systems are ideal for rapid deployments into new locations, or for sites where the need is temporary, such as at remote mines. In comparison, the terrestrial microwave systems become practical over the longer term due to their lower operating costs (Anderson T. \& Mavrakis D. 2009), (Milano Teleport, 2011), (Holmes M. 2012).

The capital expenditure to upgrade an existing terrestrial system, for example by replacing older transceivers and antennas with modern higher capacity equivalents, will be much less than that required for a completely new system. The final row of Table 1 covers this situation.

A graphical representation of the complementary nature of these systems is given in Figure 1, which shows the notional accumulation of capital-plus-operational expenditure with time. Note that the Satellite system incorporates adaptive capacity assignment, as listed in Appendix II. This reduces transponder leasing costs (and hence operational expenditure growth) for the period from initial start-up until the point of service-demand maturity is reached. 


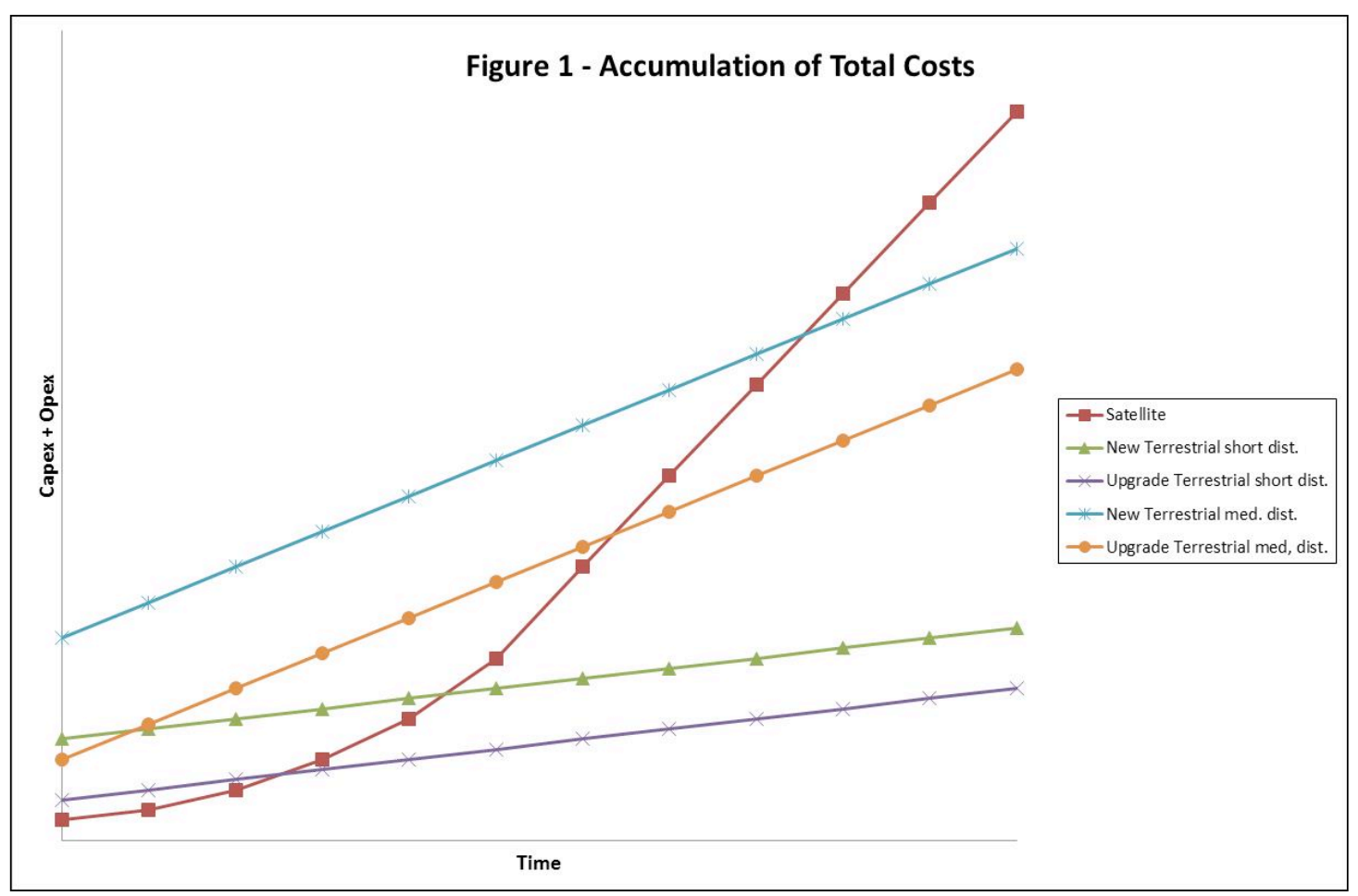

Figure 1. Notional Comparisons of Aggregated Capital + Operational Expenditure for Satellite and Terrestrial Microwave Backhaul Systems of the same maximum transmission capacity. (Satellite system costs assume a capacity-dependent lease component growing from initial start-up until maturity)

The relative costs in Table 1 and the trends depicted in Figure 1 are both conceptual and approximate. As Appendix A-III indicates, the comparisons assume terrestrial microwave systems of the basic point-to-point type. Furthermore, the respective core-network portions of the total backhaul costs are not included. So our basic purpose here is to outline the potential complementary nature of the two forms of backhaul.

The proposed study would undertake more accurate assessments. These would account for all actual factors, such as the servicing of locations with small or very small populations, or those distributed along the course of a terrestrial route and the potential for employing point-to-multi-point terrestrial systems.

\section{Coordinated deployment}

A coordinated approach employing the appropriate mix of satellite and terrestrial backhaul types would require a major financial and technical pre-study, as outlined above. Following this, the deployment program should include the following stages:

- Select candidate remote locations for new cellular mobile facilities, taking both population centres and transport movements into account. Identify the backhaul system type initially most suitable for each location e.g. satellite for locations without prospects for timely connection via terrestrial backhaul, or say upgraded HCRC terrestrial microwave for locations with short link distances. 
- Deploy cellular base stations at identified locations and connect via relevant backhaul type.

- For locations initially connected via satellite, consider progressively extending terrestrial facilities. When these become available, transfer backhaul from satellite to terrestrial. At that stage the relevant satellite facilities could then either be moved to service new locations or remain in place to provide back-up route diversity.

This coordinated approach would deliver a cost effective sequence of backhaul solutions. An initiative of this type would ensure participation by the industry. In particular, it would cause satellite backhaul for cellular mobile to be considered by the Communications Alliance (CA) Satellite Services Working Group (SSWG) set up in 2012. ${ }^{\text {ix }}$ Examination by this major influential industry body would offer the best means of ensuring any technical issues specific to cellular mobile backhaul via satellites would be taken into account. This is timely, considering that the prelaunch design and construction phase of the new Ka-Band Australian Satellites is currently taking place. Furthermore it would ensure the consideration of other potential satellites, such as the new Medium Earth Orbit (MEO) types recently launched by O3b (O3b Networks. 2011).

The cost advantages afforded by modern technological innovations make it likely that service coverage could be extended to many localities without unduly high government subsidisation. It is possible the Commonwealth Government could recover some costs by leasing out temporarily unused capacity when the new NBN Ka-Band satellites first come into service.

\section{Conclusions}

The $\$ 100 \mathrm{M}$ joint initiative planned by the newly elected Australian Government to address regional and remote cellular mobile service black spots is important. The allocated funding should serve for a substantial first stage, though subsequent further funding will be required.

To maximise cost benefits the joint program should commence with a comprehensive financial and technical investigation of backhaul and base station technology options to identify the most cost effective approaches. The scope of the study should include the provisioning of satellite and terrestrial systems in a complementary coordinated manner, shared use of existing or planned infrastructure such as the NBN and HCRC networks, and small-cell mobile base stations. 


\section{Acknowledgements}

We are grateful for various helpful comments and suggestions from:

Prof. Reg Coutts of Coutts Communications,

Tony Bundrock of Activ8me,

Ray Heffernan of the Remote Area Planning and Development Board (RAPAD), Apolline Kohen of Ninti One, and

Alan Howard of the Australian Communications Consumer Action Network (ACCAN).

We also wish to acknowledge the encouragement of Mike Crowe and John Huigen of Desert Knowledge Australia during the preparation of this paper. We have also had helpful discussions with the Northern Territory Chief Minister, Adam Giles on telecommunications requirements in outback Australia and with John Stanton of Communications Alliance. In addition a number of beneficial suggestions on content and style have been made by two reviewers and Professor Peter Gerrand, Managing Editor, Australian Journal of Telecommunications and the Digital Economy.

\section{References}

ACCAN. 2013 'ACCAN Position Statement on regional and remote mobile coverage'. ACCAN, April 2013. Available from: http://accan.org.au/files/ACCAN_Position_Statement_on_regional_and_remote_mobil e_coverage.pdf

ACCAN RTR. 2011 'Regional Telecommunications Review 2011 - Submission by the Australian Communications Consumer Action Network to the Regional Telecommunications Independent Review Committee'. ACCAN, December 2011. Available from:

http://www.google.com.au/url?sa=t\&rct=j\&q=\&esrc=s\&source=web\&cd=2\&ved=oCDIQ FjAB\&url=http\%3A\%2F\%2Faccan.org.au\%2Ffiles\%2FFINAL\%2520regional\%2520teleco mmunications\%2520review.doc\&ei=rRVJUp3JDMW1iQfsooHwDA\&usg=AFQjCNHfqt2 U5H2xFSYmo8srxl4ckoTXYQ\&bvm=bv.53217764,d.aGc

Anderson T. \& Mavrakis D. 2009 'Cellular Backhaul over Satellite'. Informa Telecoms \& Media, White Paper, 2009. Available from:

http://www.bantel.com.ve/pdf/casos_de_exito/white_paper_iDirect_celular_backhaul_ over_satellite.pdf

Aravantinos E. 2011 'Flexible microwave 4G Backhaul - Designing in \& out of the box'. Maravedis Inc. Presentation, 11th October 2011. Available from: http://www.maravedisbwa.com/assets/media/webinars/Backhaul\%2oinside\%20out\%20webinar\%20slide\%20d eck-\%20Oct\%202011.pdf

B4BA. 2013 "Extending remote and rural cellular mobile - A Broadband for the Bush Alliance discussion paper". Broadband for the Bush Alliance, May 2013. Available from: http://www.desertknowledge.com.au/getattachment/Our- 
Programs/CollaborativeImpact/Broadband-for-the-Bush-Alliance/Extending-remoteand-rural-cellular-coverage-May-2013.pdf.aspx

Bright, J. \& Mavrakis, D. 2012 'Satellite backhaul for rural small cells'. Informa Telecoms \& Media, White Paper, 2012. Available from: http://www.informatandm.com/wpcontent/uploads/2012/04/iDirect-White-Paper_online.pdf

Chambers D. 2012 'Small Cell Business Cases - The economics of satellite backhaul are changing to enable $3 \mathrm{G}$ rural small cells'. ThinkSmallCell newsletter article, December 2012. Available from: http://www.thinksmallcell.com/Rural/the-economics-of-satellitebackhaul-are-changing-to-enable-3g-rural-small-cells.html

Coalition Mobile Blackspots. 2013, authorised by B Loughnane, Barton ACT. 'The Coalition's Mobile Black Spot Programme', August 2013. Available from: http://lpawebstatic.s3.amazonaws.com/Policies/MobileBlackSpotProgramme.pdf

Coalition NBN. 2013, authorised by B Loughnane, Barton ACT. ‘The Coalition's Plan for Fast Broadband and an Affordable NBN', April 2013. Available from: http://lpawebstatic.s3.amazonaws.com/Policies/NBN.pdf.

Corner S. 2012 'Universal Telecommunications Services - A Brief History and Analysis of the Issues Surrounding the New Australian Legislation on the Universal Service Obligation'. Telecommunications Journal of Australia, Vol. 62, No. 2. pp. 22.1 - 22.9. Available from: http://doi.org/10.7790/tja.v62i2.319

Cox J. 2011 'Blending sun, satellites and cellular to connect remote locales'. Network World, 14th February 2011. Available from:

http://www.networkworld.com/news/2011/o21411-mwc-satellite-gsm.html

Croy P. 2011 'LTE Backhaul Requirements - A Reality Check'. Aviat Networks, Presentation, 13th January 2011. Available from:

http://www.aviatnetworks.com/media/files/aviat_networks_lte_backhaul_capacity.pdf

DBCDE. 2012 '2011 - 12 Regional Telecommunications Review Report'. Regional Independent Review Committee, 5 th March 2012. Available from: http://www.rtirc.gov.au/2011-12_report/

Delimiter. 2012 'WA Govt. funds Telstra mobile expansion'. News article, 1st Feb. 2012. Available from: http://delimiter.com.au/2012/02/o1/wa-govt-funds-telstra-mobileexpansion/

Engineers Australia. 2010 'Infrastructure Report Card 2010 - Telecommunications'. Separate reports for each Australian state and territory. Engineers Australia 2010. Available (for NT, Qld., SA \& WA) from:

http://www.engineersaustralia.org.au/sites/default/files/shado/Infrastructure\%2oRepor t\%20Cards/Northern/part5_telecommunications.pdf

https://www.engineersaustralia.org.au/sites/default/files/shado/Infrastructure\%2oRepo rt\%20Cards/Queensland/part5_telecommunications.pdf

http://www.engineersaustralia.org.au/sites/default/files/shado/Infrastructure\%2oRepor t\%20Cards/SA/telecommunications.pdf

http://www.engineersaustralia.org.au/sites/default/files/shado/Infrastructure\%2oRepor t\%20Cards/WA/part5_telecommunications.pdf

Featherstone D. 2011 'The Ngaanyatjarra Lands Telecommunications Project: A Quest For Broadband In The Western Desert'. Telecommunications Journal of Australia. 61 (1): Available from: http://doi.org/10.7790/tja.v61i1.186

Gibson A. 2011 'Item 11 - Strategic Issue - Mobile Phone - Issues Paper - Mobile Phone Blackspots”. NSW Farmers Association submission to ACMA CCF, July 2011: Available from: 
http://www.google.com.au/url?sa=t\&rct=j\&q=\&esrc $=$ s\&source=web\&cd=1\&ved $=0$ CDAQ FjAA\&url=http\%3A\%2F\%2Fwww.acma.gov.au\%2Fwebwr\%2F_assets\%2Fmain\%2Flib41 0020\%2Fccf_meeting_12-item11_mobile_phone_coverage-

uso_and the nbn.doc\&ei=qLtGUsmxKYyFiAeT34DQDw\&usg=AFQjCNHsYIG2dmmTV C4j7HbDoN3Nr9Qwog\&bvm=bv.53217764,d.aGc

Gilat. 2013 'Gilat and Huawei Partnering to Deliver Cellular Backhaul Solution to a Leading Southeast Asian Mobile Network Operator'. Gilat Satellite Networks, Press Release 16th January 2013. Available from:

http://www.gilat.com/dynimages/t_press_releases/files/2013-0116\%20Gilat\%20and\%20Huawei\%20Partnering\%20to\%20Deliver\%20Cellular\%2oBackha ul\%20Solution\%20.pdf

Giles A. 2013 'Telstra in Partnership with The Territory'. Northern Territory Government Media Release, 16th April 2013. Available from: http://newsroom.nt.gov.au/index.cfm?fuseaction=viewRelease\&id=10640\&d=5

Guo J. 2009 'CSIRO Submission 09/348 - Department of Broadband Communications and the Digital Economy - Response to the Blackspots Initiative Stakeholder Consultation Paper'. Submission to Australian Commonwealth Government Backhaul Black Spots Initiative. CSIRO, May 2009. Available from: http://www.communications.gov.au/_data/assets/pdf_file/o004/113458/CSIRO.pdf

Holmes M. 2012 'Cellular Backhaul: Where Does Satellite Fit In?'. Via Satellite, 1st January 2012. Available from: http://www.satellitetoday.com/via/features/Cellular-BackhaulWhere-Does-Satellite-Fit-In_38028.html

Hutchinson J. 2012 'Telstra kills point-to-point radio shutdown'. iTnews, 30th March 2012. Available from: http://www.itnews.com.au/News/295417,telstra-kills-point-to-pointradio-shutdown.aspx

iDirect. 2009 'Eight Essentials to Implementing Backhaul over Satellite for Mobile Operators'. iDirect White Paper, June 2009. Available from: http://www.idirect.net/ /media/Files/Cellular\%2oBackhaul\%20Campaign/Eight\%2oEs sentials\%20for\%20Cellular\%20Backhaul\%200ver\%20Satellite.ashx

Informa. 2012 'The Case for Rural data services and satellite backhaul'. Informa Telecoms \& Media, 2012. White Paper, 2012. Available from: http://www.informatandm.com/whitepapers/

Intelsat. 2010 'Intelig Secures Capacity on Intelsat 14 to Expand Cellular Backhaul Services in Brazil'. Company Press Release, 24th May 2010. Available from: http://www.intelsat.com/press/news-releases/2010/20100524-1.asp

Jain A. K; Katiyar S. \& Agrawal N. K. 2011 'Hierarchical Cellular Structures in High-Capacity Cellular Communication Systems'. International Journal of Advanced Computer Science and Applications, Vol. 2, No. 9, 2011, pp. 51-57. Available from: http://arxiv.org/pdf/1110.2627.pdf

Joint Committee on the NBN. 2013 'Review of the Rollout of the National Broadband Network - Fourth Report'. Parliament of the Commonwealth of Australia, Canberra, 26 Feb. 2013. Available from: http://apo.org.au/sites/default/files/docs/JointCommitteeBroadband_FourthReport_Fe bruary2103.pdf

Karlsson R. S. 1999 'Sharing Radio Resources in Hierarchical Cell Structures Utilizing Slow Frequency Hopping'. IEEE 49th Veh. Tech. Conf., Houston TX. Available from:

http://citeseerx.ist.psu.edu/viewdoc/summary?doi=10.1.1.27.2181 
Knoll Y. 2009 'Enabling Rural Broadband Services with Wireless Backhaul'. Ceragon Networks White Paper, October 2009. Available from:

http://www.ceragon.com/files/library/Enabling_Rural_Broadband_Services.pdf.pdf

LingSun Tan et. al. 2011 LingSun Tan, SeiPing Lau and ChongEng Tan. 'Improving Qualityof-Service of Real-Time Applications over Bandwidth Limited Satellite Communication Networks via Compression'. University of Malaysia, Sarawak, Malaysia. Published in Advances in Satellite Communications, Dr. Masoumeh Karimi (Ed). ISBN: 978-953-307562-4. Available from: http://cdn.intechopen.com/pdfs/16869/InTech-

Improving_quality_of_service_of_real_time_applications_over_bandwidth_limited_sa tellite_communication_networks_via_compression.pdf

Mavrakis D. White C and Benlamlih F. 2010 'Last Mile Options for Western European Mobile Operators'. Independent Research Paper by Informa Telecoms \& Media, 2010. Available from: http://cbnl.com/sites/all/files/userfiles/files/Last-Mile-BackhaulOptions-for-West-European-Mobile-Operators.pdf

Milano Teleport. 2011 'Cellular Backhaul Solutions'. Milano Teleport company presentation. Available from:

http://www.milanoteleport.com/new/images/pdfs/milano_teleport_cellular_backhaul_ solutions.pdf

O3b Networks. 2011 'Technology Overview'. O3b Networks, Company Brochure. Available from: http://www.o3bnetworks.com/media/6437/o3b\%20technology\%20overview.pdf

O3b \& Sofrecom 'Why Latency Matters to Mobile Backhaul'. O3b Networks and Sofrecom White Paper. Available from:

http://www.o3bnetworks.com/media/45606/latency\%20matters.pdf

Optus. 2011 'Optus Submission To Regional Telecommunications Independent Review Committee; 2011-12 Regional Telecommunications Review'. Optus; December 2011, sections 6.1 \& 6.5. Available from: http://www.rtirc.gov.au/files/2011/12/Optus.pdf

Pigg J. M. 2010 'Mobile Backhaul Evolution'. Yankee Group Presentation, 27th April 2010. Available from: http://www.slideshare.net/yankeegroup/mobile-backhaul-evolution

Radio-Electronics.com 'Cellular Concepts and Basics' Web tutorial. Available from: http://www.radio-electronics.com/info/cellulartelecomms/cellular_concepts/mobilebasics-concepts.php

RADWIN Ltd. 2009 'Cellular Backhaul Solutions - Reaching Out to Rural Areas'. Radwin Ltd. Application Brochure. Available from: http://www.radwin.com/contentManagment/uploadedFiles/fileGallery/Brochures/Appli cations/Cellular_Backhaul_-_Emerging_Markets.pdf

RAPAD. 2009 'Central Western Queensland Remote Area Planning and Development Board (RAPAD) - Response to the Australian Governments Backhaul Blackspots Initiative Stakeholder Consultation Paper'. Attachment A of RAPAD 2009 submission. Available from: http://www.communications.gov.au/__data/assets/pdf_file/o015/113433/RAPAD.pdf

Talbot D. 2010 'A 50-Watt Cellular Network - Solar-powered base stations can link up remote rural areas'. Technology Review, 10th February 2010. Available from: http://www.technologyreview.com/news/417442/a-50-watt-cellular-network/

Telstra. 2011 '2011 - 12 Regional Telecommunications Review - Submission from Telstra'. Telstra Corporation Ltd., 16th December 2011, page 7. Available from:http://www.rtirc.gov.au/files/2011/12/Telstra.pdf 
Venkatramani V. 2010 'Birdsville finally gets $3 \mathrm{G}$ mobile coverage'. North Queensland Register, 24th August 2010. Available from:

http://www.northqueenslandregister.com.au/news/state/agribusiness/generalnews/birdsville-finally-gets-3g-mobile-coverage/1920677.aspx

Yablonski S. 2012 'Mobile data explosion makes Ka Band satellite profitable in LTE backhaul'. TelecomEngine, Telecommunications Media Group, 25th Apr. 2012. ailable from: http://www.telecomengine.com/article/mobile-data-explosion-makes-ka-bandsatellite-profitable-lte-backhaul

\section{Acronyms}

ACCAN Australian Communications Consumer Action Network

B4B Broadband for the Bush

B4BA Broadband for the Bush Alliance

DCDBE Department of Communications, Broadband and the Digital Economy

DRCS Digital Radio Concentrator System

HCRC High Capacity Radio Concentrator

MEO Medium Earth Orbit

NBN National Broadband Network

NT Northern Territory

QoS Quality of Service

RAPAD Central Western Queensland Remote Area Planning and Development Board

STS Standard Telephone Service

USO Universal Service Obligation

VSAT Very Small Aperture Terminal

WA Western Australia 


\section{Appendix I - Delineation of Australian Remoteness Areas}

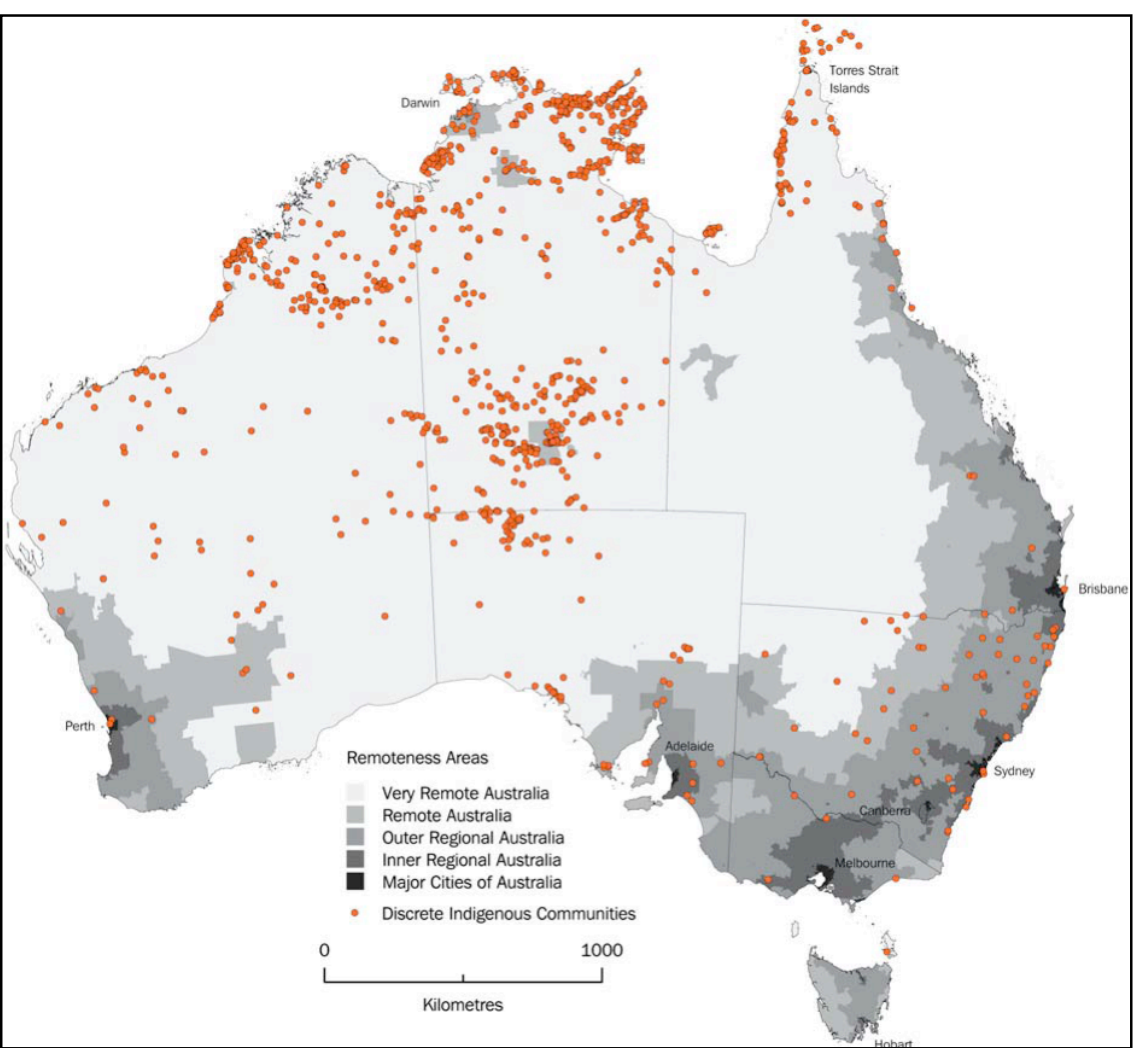

Figure Al-1. Remoteness Areas of Australia (Australian Bureau of Statistics)

\section{Appendix II - Advances in Modern Communications Satellite Technology}

Table All-1. Advances of Modern Communications Satellite Technologies

\begin{tabular}{|c|c|}
\hline Feature & Main Advantages \\
\hline $\begin{array}{l}\text { TDMA transmission (as opposed to } \\
\text { traditional Single Channel Per Carrier) }\end{array}$ & 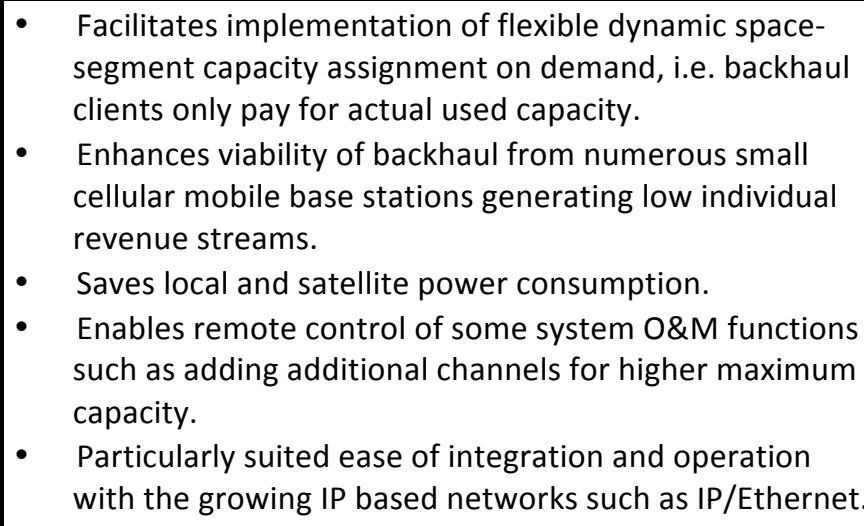 \\
\hline $\begin{array}{l}\text { Transponder circuit board } \\
\text { miniaturisation, Gallium nitride power } \\
\text { amplification }\end{array}$ & $\begin{array}{ll}\text { - } & \text { Reduced launch costs } \\
\text { - } & \text { Greater transponder power efficiencies } \\
\text { - } & \text { Increased satellite maximum capacity. }\end{array}$ \\
\hline
\end{tabular}




\begin{tabular}{|c|c|}
\hline Feature & Main Advantages \\
\hline $\begin{array}{l}\text { Local (i.e. terrestrial) call routing at } \\
\text { remote Cellular Mobile Base Stations }\end{array}$ & $\begin{array}{l}\text { - } \quad \text { Reduces space-segment traffic. } \\
\text { - } \quad \text { Saves local and satellite power consumption. } \\
\text { - } \quad \text { Removes double satellite-path latency from local calls. }\end{array}$ \\
\hline Adaptive fade margin control & $\begin{array}{l}\text { - } \quad \text { Saves local and satellite power consumption. } \\
\text { Enhances space-segment spectral efficiency when each } \\
\text { satellite beam serves numerous remote sites distributed } \\
\text { across the ground service area. }\end{array}$ \\
\hline $\begin{array}{l}\text { Optimised voice and data } \\
\text { compression }\end{array}$ & $\begin{array}{l}\text { - Promotes greater space-segment transmission } \\
\text { efficiency. }\end{array}$ \\
\hline Ka - Band Satellites & $\begin{array}{l}\text { Much higher capacities due to the combined effect of } \\
\text { greater available bandwidths \& the practicality of } \\
\text { employing significantly increased numbers of spot- } \\
\text { beams. } \\
\text { Because the introduction of these new satellite types } \\
\text { has begun quite recently they are designed and built to } \\
\text { include the latest innovations for providing improved } \\
\text { transmission efficiencies. }\end{array}$ \\
\hline Medium Earth Orbit (MEO) satellites & $\begin{array}{l}\text { - } \quad \text { Lower launch costs leading to lower cost capacity } \\
\text { leasing } \\
\text { - } \quad \text { Much reduced transmission latency }\end{array}$ \\
\hline
\end{tabular}

\section{Appendix III - Assumed Cost Category Allocation for Satellite and Terrestrial Microwave System Comparisons}

For the purposes of discussing comparative costings of satellite and terrestrial microwave backhaul systems we make the following assumptions: -

- Satellite system transponder capacity is leased. Thus the high space segment development and launch costs and the main earth station development and construction and its ongoing operational costs are all amortised by the leasing, which is therefore accounted as OpEx by the backhaul Network Operators.

- Installation of satellite system remote earth terminals is undertaken by the backhaul Network operator and accounted as CapEx. Ongoing remote earth terminal operational costs are accounted as OpEx.

- The remote location served is typical of a remote township or community, say with a population of the order of one to two hundred.

- The terrestrial microwave systems are of the basic point-to-point type running via a number of successive hops from the core network boundary to the remote location. 
- New terrestrial microwave systems are installed and operated by the backhaul Network Operator. So all construction, equipment and installation costs are CapEx and all ongoing operational costs are OpEx.

- For an upgraded existing terrestrial microwave system it is assumed that all costs incurred in replacing older infrastructure components and equipment with new counterparts, changes such as tower strengthening or alternate guying and new system start-up costs are accounted as CapEx. OpEx costs are assumed to be the same as those for a comparable new terrestrial microwave system covering the same terrain and total route distance.

\section{Endnotes}

i Within Australia somewhat variable interpretations have come to apply to the terms "regional" and "remote". In the present context and to be more definitive, the areas most likely to be without cellular mobile services will generally be in parts of the "Outer Regional", the "Remote" and the "Very Remote" categories defined in the detailed Australian Bureau of Statistics map shown in Appendix I.

ii ACCAN (ACCAN. 2013) the 2012 Broadband for the Bush forum and the Broadband for the Bush Alliance (B4BA. 2013) are examples of bodies that have recently voiced calls for regional and remote cellular mobile coverage to be addressed. Somewhat earlier calls have been made by the NSW Farmers' Association (Gibson A. 2011) and Engineers Australia (Engineers Australia. 2010).

iii Some examples of optical fibre routes in remote and regional Australia are shown in the telecommunications infrastructure map appended to the Central Western Queensland Remote Area Planning and Development Board (RAPAD) response to the 2009 Australian Government Backhaul Blackspots initiative (RAPAD. 2009).

iv We are unaware of any definitive public domain source covering backhaul media cost comparisons. However approximate indications can be deduced by examining material from various sources. For example helpful CapEx estimates for various optical fibre and terrestrial microwave system types traversing farmland or desert terrain, with tower costs for the latter systems included, are provided in the CSIRO submission by Guo (Guo J. 2009). Furthermore, the modeled total annualized cost estimates provided by Mavrakis, White and Banlamlih for a typical Tier-1 UK Mobile Operator (Mavrakis D. White C. and Benlamlih F. 2010.) and the less detailed CapEx comparisons given in slides 30 to 32 of 
the set produced by Pigg (Pigg J.M. 2010) while not being directly relevant to rural Australia, nevertheless point to appreciable cost advantages of terrestrial microwave over optical fibre systems generally.

$\mathrm{v}$ In certain cases the installation of a Macro-cell base station may still be warranted. For example if a small remote community is near a significant highway, then the additional coverage range may justify the larger and more powerful installation.

vi One good example showing terrestrial microwave systems in a part of regional and remote Australia is provided by the map included in the Central Western Queensland Remote Area Planning and Development Board (RAPAD) response to the 2009 Australian Government Backhaul Blackspots initiative (RAPAD. 2009). The map shows various existing terrestrial microwave backhaul links feeding out from optical fibre main routes. It also shows HCRC and DRCS system routes in the Central Western Queensland area.

vii Satellite transponder capacity is almost invariably leased by Network Operators from specialist companies or in some cases government entities that bear the high development, construction and launch costs.

viii Although the comparisons provided by Table 1 are of a qualitative rather than a quantitative nature, they are founded on numerous reports including some of those referenced here. There is some natural variability of emphasis across all of this material. However practically all other accounts sighted by the authors support the results provided here and none have been contradicting. Therefore these present comparisons are considered to provide adequate justification for undertaking the further in-depth investigations advocated.

ix Currently the issues being addressed by the SSWG include:

1. Advocacy on behalf of the satellite sector, including via input to State and Federal Government policy development and Inquiries, and through representation of satellite sector interests on the ACMA's Radiocommunications Consultative Committee (RCC)

2. Participation on the ACMA Australian Radiocommunications Study Group 4, Satellite services (ARSG 4)

3. Contributing to the ACMA spectrum management planning work program, including their Five-year Spectrum Outlook 2012-2016

4. General promotion of the role and importance of satellite services for Australia through the Satellite Industry Promotion Campaign 
5. Liaison with NBN Co on operational and commercial issues relating to the satellite-based components of the National Broadband Network

6. Expert input into the creation or revision of Communications Alliance Codes, Guidelines and Standards that have implications for satellite-based services

7. Collaborative activities to foster the development and growth of the satellite sector in Australia and to resolve technical or commercial issues of common interest

8. Monitoring of international standards work relevant to the Australian satellite sector.

Cite this article as: Crouch, Andrew; Davies, Stan. 2013. 'A coordinated satellite and terrestrial microwave backhaul for cellular mobile in remote and regional Australia'. Australian Journal of Telecommunications and the Digital Economy 1 (1): pp.2.1 - 2.19.

DOI: 10.7790/ajtde.v1n1.2 Available at: http://telsoc.org/journal 